\title{
Plasma Glutamate Concentrations in 1-Year-Old Infants and Adults Ingesting Monosodium L- Glutamate in Consommé ${ }^{1}$
}

\author{
LEWIS D. STEGINK, L. J. FILER, JR, GEORGE L. BAKER, AND EDWARD F. BELL \\ Departments of Pediatrics and Biochemistry, The University of Iowa College of Medicine, Iowa City, Iowa 52242
}

\begin{abstract}
This study tested the hypothesis that infants metabolize glutamate more slowly than adults. Eight 1-yrold infants ingested $160 \mathrm{ml}$ of a beef consommé providing monosodium L-glutamate at 0,25 , and $50 \mathrm{mg} / \mathrm{kg}$ body weight. Plasma glutamate and aspartate concentrations were measured sequentially for the next $2 \mathrm{~h}$. The results were compared to values noted in nine adult subjects ingesting equivalent doses of monosodium L-glutamate in consommé. In adults, mean ( \pm SD) peak plasma glutamate concentrations were $5.59 \pm 1.56,10.2 \pm 2.08$, and $17.0 \pm$ $8.06 \mu \mathrm{mol} / \mathrm{dl}$, respectively; the area under the plasma glutamate concentration time curves were $96 \pm 42,257 \pm 80$, and $442 \pm 303 \mu \mathrm{mol} / \mathrm{dl} \times \mathrm{min}$, respectively. In infants, the mean $( \pm \mathrm{SD})$ peak plasma glutamate concentrations were $6.94 \pm 1.43,10.6 \pm 2.36$, and $12.0 \pm 1.16 \mu \mathrm{mol} / \mathrm{dl}$, respectively; the plasma glutamate area under the curve values were $47 \pm 28,191 \pm 85$, and $358 \pm 105 \mu \mathrm{mol} / \mathrm{dl} \times \mathrm{min}$, respectively. The data indicate that the plasma glutamate concentration response in 1-yr-old infants ingesting MSG at these glutamate doses is no higher than values observed in adult subjects. (Pediatr Res 20: 53-58, 1986)
\end{abstract}

Abbreviations

AUC, area under the curve

MSG, monosodium L-glutamate

ANOVA, analysis of variance

The ability of human infants to metabolize MSG has been one area of concern in considering glutamate's safety as a food additive. Olney (1-3) postulated that human infants metabolized dicarboxylic amino acids more slowly than adults, and projected theoretical plasma glutamate concentrations for infants at much higher values than those for adults following glutamate ingestion.

The present study directly tested this hypothesis by measuring the plasma glutamate and aspartate response in 1-yr-old infants fed a beef consommé containing graded doses of MSG. The results of these studies were compared with previously reported (4) plasma glutamate and aspartate values in normal adults administered equivalent doses of MSG in the same consommé.

Received March 19, 1985; accepted August 21, 1985

Correspondence and reprint requests should be addressed to Dr. Lewis D. Stegink, Department of Pediatrics, S385 Hospital School, The University of Iowa, Iowa City, IA 52242.

Supported in part by a grant-in-aid from The International Glutamate Technical Committee.

${ }^{1}$ These data were presented in preliminary form at the American Institute of Nutrition Meeting, April, 1983, Fed Proc 42:1311.

\section{MATERIALS AND METHODS}

Eight infants (four male, four female) were studied. The proposed study was explained to at least one of the parents and informed, written consent was obtained. The protocol of the study was reviewed and approved by the Committee on Research Involving Human Subjects of the University of Iowa.

Each child ingested $160 \mathrm{ml}$ of beef consommé providing 0,25 , and $50 \mathrm{mg} / \mathrm{kg}$ body weight of added MSG in a balanced crossover design. Each infant was randomly assigned to receive consommé providing either 0 or $25 \mathrm{mg} \mathrm{MSG} / \mathrm{kg}$ body weight, followed by the other dose at least 1 wk later. After these two tests had been completed and the results evaluated, each infant ingested consommé providing MSG at $50 \mathrm{mg} / \mathrm{kg}$ body weight. All tests were begun at $0800 \mathrm{~h}$ following an overnight fast.

The monohydrate of monosodium L-glutamate was purchased from a local grocery store (Accent International, Pet Incorporated, St. Louis MO). The soup was prepared from a special beef consommé base supplied by the Ajinomoto Company (Tokyo, Japan). The composition of the soup base is shown in Table 1 . As noted in Table 1, $160 \mathrm{ml}$ of reconstituted soup contained 37 $\mathrm{mg}$ of free glutamate, for a mean dose of $4.1 \mathrm{mg} / \mathrm{kg}$ body weight. Thus, the true final doses of MSG studied in these infants were $4.1,29.1$ and $54.1 \mathrm{mg} / \mathrm{kg}$ body weight.

Each infant was assigned by random allocation into one of two equal groups that differed with respect to time of blood sampling. Since only four blood samples were obtained from each infant after dosing, two different sampling schedules were utilized so as to obtain samples during the entire absorptive period. Blood samples at each dose level were obtained from four infants at $0,30,60$, and 120 min After ingestion of the consommé. Blood samples from the other four infants were obtained at $0,15,45$, and $90 \mathrm{~min}$.

Blood samples were obtained by heel skin puncture using the precautions described by Stegink et al. (5) for appropriate collection of capillary blood. These samples were processed and analyzed as previously described (4).

Values for infants were compared with values previously obtained for normal adult subjects (4). In the latter study, nine adult subjects (five male, four female) were studied in a Latin square design (three subjects/cell) using three different servings of the same beef consommè. The consommè was administered at a level of $4.2 \mathrm{ml} / \mathrm{kg}$ body weight and provided added MSG at 0,25 , and $50 \mathrm{mg} / \mathrm{kg}$ body weight. Blood samples for amino acid analyses were collected at $0,15,30,45,60,90,120,150,180$, and $240 \mathrm{~min}$ after ingestion of the consommé.

Statistical analyses were carried out using the paired $t$ test and ANOVA $(6,7)$. Results were assessed for statistical significance both before and after application of the Bonferroni correction (8). The Bonferroni procedure is a simple method for controlling type I error (differences due to chance alone) during multiple 
Table 1. Composition of beef consommé soup used*

\begin{tabular}{lc}
\hline Component & \% dry wt \\
\hline Crude protein & 6.4 \\
Fat & 11.3 \\
Carbohydrate & 22.5 \\
Ash & $56.0 \dagger$ \\
Water & 1.6 \\
Free glutamate & 1.2 \\
\hline
\end{tabular}

* Soup base reconstituted at a level of $1.94 \mathrm{~g}$ base $/ 100 \mathrm{ml}$ hot water. Soup reconstituted at this level provides $4.1 \mathrm{mg} \mathrm{MSG} / \mathrm{kg}$ body weight and $77 \mathrm{mg}$ carbohydrate $/ \mathrm{kg}$ body weight when $160 \mathrm{ml}$ is fed to a $9.1 \mathrm{~kg}$ infant. Adult subjects ingested $4.3 \mathrm{ml}$ of reconstituted soup per $\mathrm{kg}$ body weight. This level provides approximately $1 \mathrm{mg} \mathrm{MSG} / \mathrm{kg}$ body weight and $18.8 \mathrm{mg}$ carbohydrate $/ \mathrm{kg}$ body weight.

$\uparrow 54.4 \%$ of this sodium chloride.

application of the $t$ test to a set of data (8). Plasma amino acid values at each time point following the loading dose were compared to zero time values. The area under the plasma timeconcentration curve for each amino acid was calculated using the summation of the trapezoidal areas between plasma values at successive time points. The base of each trapezoid was set as the normal fasting level for that amino acid. The AUC is expressed as $\mu \mathrm{mol} / \mathrm{dl} \times \mathrm{min}$.

\section{RESULTS}

Table 2 lists infant weight, age, and the time required for the infants to ingest the soup. The age and weight of infants ingesting MSG at 0 and $25 \mathrm{mg} / \mathrm{kg}$ body weight were similar, as expected. Because the $50 \mathrm{mg} / \mathrm{kg}$ body weight dose of MSG was studied last, the infants were older and larger.

The mean time of soup ingestion by infants was $18 \mathrm{~min}$ and did not vary with the dose of MSG. This was slower than the ingestion rate observed in adults, where only 7 min were needed to drink the soup.

Plasma glutamate and aspartate concentrations in infants and adults ingesting soup without added MSG are shown in Table 3. Baseline values for both glutamate and aspartate were significantly lower ( $p<0.005$ ANOVA, Bonferroni correction applied) in adults than in infants. The reason for this difference is unknown, but it has been observed in previous studies with other nitrogen sources $(9,10)$. The ingestion of consommè without added MSG increased slightly, but not significantly, mean plasma glutamate concentrations over baseline values in both infants and adults. The peak increase over baseline plasma glutamate concentration was slightly, but not significantly, larger in adults $(+1.9 \mu \mathrm{mol} / \mathrm{dl})$ than in infants $(+0.7 \mu \mathrm{mol} / \mathrm{dl})$. Similarly, the area under the 2-h plasma glutamate concentration-time curve (AUC) in adults was slightly, but not significantly, higher than the 2-h AUC value in infants. No significant change in plasma aspartate concentration was noted after ingestion of soup without added MSG in either infants or adults. The peak increase over the baseline plasma aspartate concentration was slightly higher in infants $(+0.29 \mu \mathrm{mol} / \mathrm{dl})$ than adults $(+0.04 \mu \mathrm{mol} / \mathrm{dl})$ as was the AUC value; neither difference was statistically significant.

Plasma glutamate and aspartate concentrations in infants and adults ingesting consommé providing added MSG at $25 \mathrm{mg} / \mathrm{kg}$ body weight are shown in Table 4 . Glutamate ingestion significantly increased mean $( \pm$ SD) plasma glutamate concentration in adults from a baseline value of $3.93 \pm 1.10 \mu \mathrm{mol} / \mathrm{dl}$ to a peak value of $10.2 \pm 2.08 \mu \mathrm{mol} / \mathrm{dl} 30 \mathrm{~min}$ after dosing. A similar response was noted in infants, where the mean plasma glutamate concentration increased from a baseline value of $7.22 \pm 1.19$ $\mu \mathrm{mol} / \mathrm{dl}$ to a peak value of $10.6 \pm 2.37 \mu \mathrm{mol} / \mathrm{dl} 15 \mathrm{~min}$ after ingestion. The increase in infants was significant using paired $t-$ test analysis $(p<0.05)$, but was not significant when the data were analyzed by ANOVA. The increase over the baseline plasma
Table 2. Age, wt, and time required to ingest soup of participating infants (mean $\pm S D$ )

\begin{tabular}{cccc}
\hline $\begin{array}{c}\text { Group } \\
(\mathrm{mg} / \mathrm{kg})\end{array}$ & Age (days) & Wt $(\mathrm{kg})$ & $\begin{array}{c}\text { Time required } \\
\text { to drink soup (min) }\end{array}$ \\
\hline 0 & $305 \pm 55$ & $9.10 \pm 1.18$ & $18.5 \pm 6.8$ \\
25 & $299 \pm 54$ & $9.08 \pm 1.17$ & $16.6 \pm 4.2$ \\
50 & $317 \pm 61$ & $9.28 \pm 1.29$ & $19.0 \pm 7.1$ \\
\hline
\end{tabular}

Table 3. Plasma glutamate and aspartate concentrations in young infants and adults ingesting soup with no added $M S G$

\begin{tabular}{lccccc}
\hline \multirow{2}{*}{$\begin{array}{c}\text { Time } \\
\text { (h) }\end{array}$} & \multicolumn{2}{c}{ Plasma glutamate } & & \multicolumn{2}{c}{ Plasma aspartate } \\
\cline { 2 - 3 } \cline { 5 - 6 } & Infants & Adults* & & Infants & Adults* \\
\hline 0 & $6.24 \pm 1.52 \dagger$ & $3.69 \pm 1.08 \ddagger$ & & $1.25 \pm 0.36 \dagger$ & $0.70 \pm 0.50 \ddagger$ \\
0.25 & $6.54 \pm 0.71$ & $5.59 \pm 1.56$ & & $1.37 \pm 0.34$ & $0.74 \pm 0.62$ \\
0.5 & $6.94 \pm 1.43$ & $5.44 \pm 1.15$ & & $1.53 \pm 0.41$ & $0.71 \pm 0.45$ \\
0.75 & $6.11 \pm 0.82$ & $5.36 \pm 1.57$ & & $1.54 \pm 0.32$ & $0.69 \pm 0.60$ \\
1.0 & $6.52 \pm 1.85$ & $4.86 \pm 1.49$ & & $1.18 \pm 0.52$ & $0.65 \pm 0.44$ \\
1.5 & $6.15 \pm 1.10$ & $4.26 \pm 1.28$ & & $1.29 \pm 0.43$ & $0.68 \pm 0.50$ \\
2.0 & $5.53 \pm 1.50$ & $4.13 \pm 1.77$ & & $1.32 \pm 0.49$ & $0.63 \pm 0.51$ \\
& & & & \\
AUC\& & $48.6 \pm 28.3$ & $94.5 \pm 41.5$ & $6.83 \pm 0.30$ & $-2.18 \pm 1.35$ \\
\hline
\end{tabular}

* Data in adults taken from Reference 3 .

$\dagger$ Data expressed as mean $\pm \mathrm{SD}$ in $\mu \mathrm{mol} / \mathrm{dl} ; n=8$ at zero time and $n$ $=4$ at all other time points.

$\ddagger$ Data expressed as mean $\pm \mathrm{SD}$ in $\mu \mathrm{mol} / \mathrm{dl} ; n=9$ at all time points.

$\S$ Expressed as mean $\pm \mathrm{SD}$ in $\mu \mathrm{mol} / \mathrm{dl} \times \mathrm{min}$.

glutamate value was slightly higher in adults $(+6.27 \mu \mathrm{mol} / \mathrm{dl})$ than in infants $(+3.38 \mu \mathrm{mol} / \mathrm{dl})$ but the difference was not statistically significant. Similarly, the plasma glutamate AUC value in adults $(257 \pm 79.6 \mu \mathrm{mol} / \mathrm{dl} \times \mathrm{min})$ did not differ significantly from the value in infants $(191 \pm 84.7 \mu \mathrm{mol} / \mathrm{dl} \times$ $\mathrm{min}$ ). Plasma aspartate concentration increased slightly, but not significantly, in both infants and adults. In adults, ingestion of consommé providing $25 \mathrm{mg} / \mathrm{kg}$ body weight of added MSG increased mean plasma aspartate concentrations significantly (ANOVA) from a baseline value of $0.66 \pm 0.53 \mu \mathrm{mol} / \mathrm{dl}$ to a peak value of $1.12 \pm 0.70 \mu \mathrm{mol} / \mathrm{dl} 30 \mathrm{~min}$ after ingestion. Mean plasma aspartate concentration also increased in infants, but the change was not statistically significant. The peak increases in plasma aspartate concentration over baseline values in adults $(+0.46 \mu \mathrm{mol} / \mathrm{dl})$ and infants $(+0.61 \mu \mathrm{mol} / \mathrm{dl})$ were not significantly different nor were the plasma AUC values.

Plasma glutamate and aspartate concentrations in infants and adults ingesting soup providing $50 \mathrm{mg} / \mathrm{kg}$ body weight added MSG are shown in Table 5. In adults, mean ( \pm SD) plasma glutamate concentration increased significantly from a baseline value of $3.77 \pm 0.80 \mu \mathrm{mol} / \mathrm{dl}$ to a peak value of $17.0 \pm 8.06$ $\mu \mathrm{mol} / \mathrm{dl} 30 \mathrm{~min}$ after soup ingestion. In infants the mean plasma glutamate concentration increased significantly from a base line value of $6.71 \pm 1.14 \mu \mathrm{mol} / \mathrm{dl}$ to a peak value of $12.0 \pm 1.16$ $\mu \mathrm{mol} / \mathrm{dl} 15 \mathrm{~min}$ after soup ingestion. Although the mean peak increase over baseline concentration in adults $(+13.2 \mu \mathrm{mol} / \mathrm{dl})$ was significantly greater ( $p<0.005$, ANOVA, Bonferroni correction applied) than in infants $(+5.29 \mu \mathrm{mol} / \mathrm{dl})$, plasma glutamate AUC values did not differ significantly. Ingestion of consommé providing $50 \mathrm{mg} / \mathrm{kg}$ body weight MSG produced only small changes in plasma aspartate concentration. In adults, mean $( \pm \mathrm{SD})$ plasma aspartate concentration increased significantly $(p$ $<0.005$, ANOVA, Bonferroni correction applied) from a baseline value of $0.43 \pm 0.19 \mu \mathrm{mol} / \mathrm{dl}$ to a peak value of $1.40 \pm 0.71$ $\mu \mathrm{mol} / \mathrm{dl} 30 \mathrm{~min}$ after dosing. In infants, the increase in the mean plasma aspartate concentration was smaller and not statistically significant. The increase over the mean baseline value was similar in adults $(+0.97 \mu \mathrm{mol} / \mathrm{dl})$ and infants $(+0.70 \mu \mathrm{mol} / \mathrm{dl})$, as were 
Table 4. Plasma glutamate and aspartate concentrations in infants and adults ingesting soup with $25 \mathrm{mg} / \mathrm{kg}$ body wt added MSG

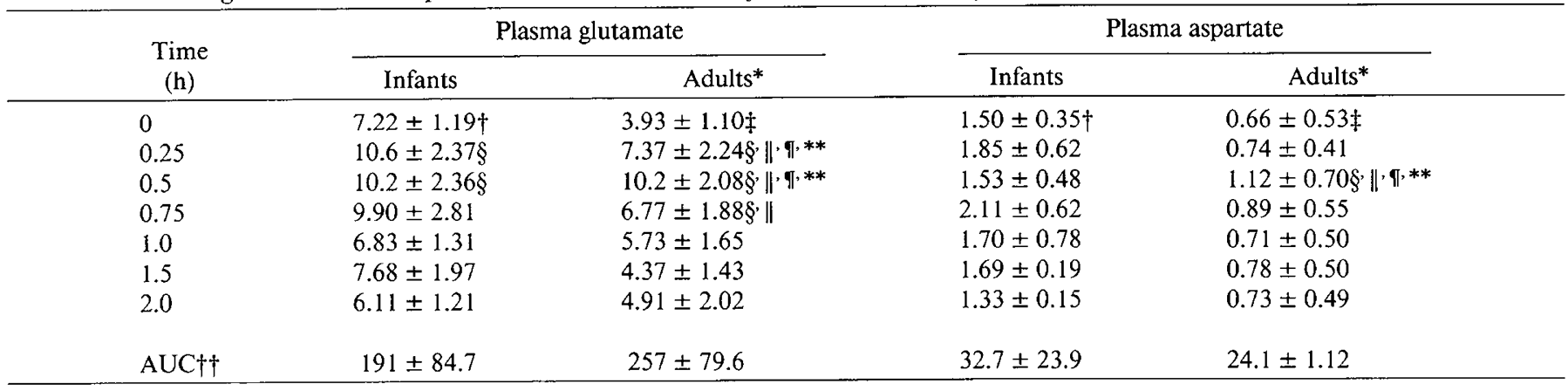

* Data in adults taken from Reference 3.

+ Data expressed as mean $\pm \mathrm{SD}$ in $\mu \mathrm{mol} / \mathrm{dl} ; n=8$ at zero time and $n=4$ at all other time points.

$\$$ Data expressed as mean $\pm \mathrm{SD}$ in $\mu \mathrm{mol} / \mathrm{dl} ; n=9$ at all time points.

$\S$ Values differed significantly ( $p<0.05$, paired $t$ test) from baseline values.

$\|$ Values differ significantly $(p<0.005$, ANOVA, Bonferroni correction applied) from baseline values.

I Values differ significantly ( $p<0.05$, paired $t$ test) from values when MSG is not added.

** Values differ significantly ( $p<0.005$, ANOVA, Bonferroni correction applied) from values when MSG is not added.

$\dagger \dagger$ Expressed as mean $\pm \mathrm{SD}$ in $\mu \mathrm{mol} / \mathrm{dl} \times \min$.

Table 5. Plasma glutamate and aspartate concentrations in infants and adults ingesting soup with $50 \mathrm{mg} / \mathrm{kg}$ body wt added MSG

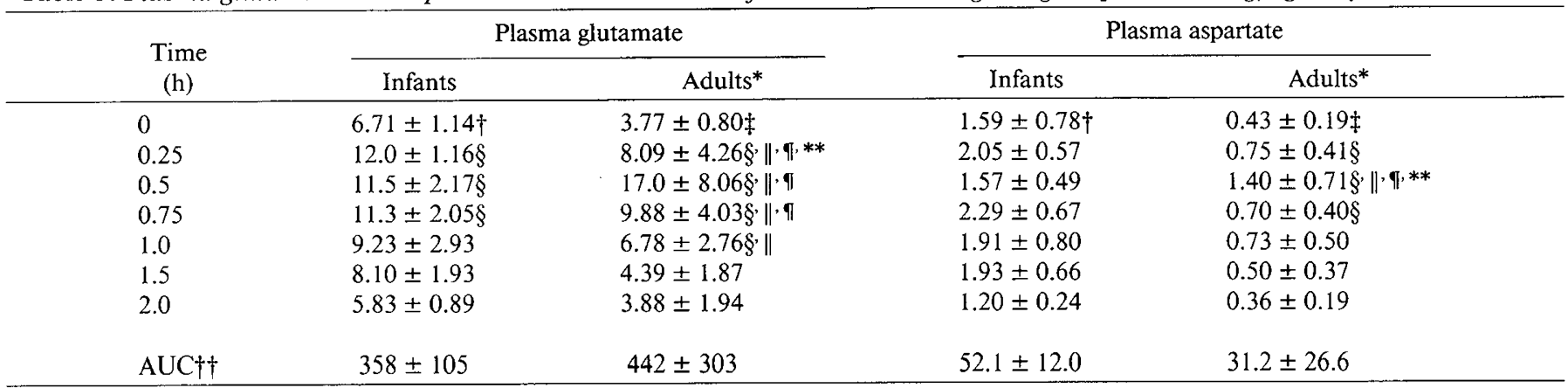

* Data in adults taken from Reference 3 .

$\uparrow$ Data in infants expressed as mean \pm SD in $\mu \mathrm{mol} / \mathrm{dl} ; n=8$ at zero time and $n=4$ at all other time points.

$\$$ Data in adults expressed as mean $\pm \mathrm{SD}$ in $\mu \mathrm{mol} / \mathrm{dl} ; n=9$ at all time points.

$\S$ Values differ significantly from baseline values, $p<0.05$, paired $t$ test.

$\|$ Values differ significantly ( $p<0.005$, ANOVA, Bonferroni correction applied) from baseline values.

If Values differ significantly ( $p<0.005$, ANOVA, Bonferroni correction applied) from values when MSG was not added.

** Values differ significantly ( $p<0.005$, ANOVA, Bonferroni correction applied) from values when MSG is ingested at $25 \mathrm{mg} / \mathrm{kg}$ body wt.

$\dagger \dagger$ Expressed as mean $\pm \mathrm{SD}$ in $\mu \mathrm{mol} / \mathrm{dl} \times \mathrm{min}$.

the AUC values. Neither value differed significantly between infants and adults.

Erythrocyte glutamate and aspartate concentrations were also measured in these infants. No significant increase in erythrocyte glutamate or aspartate concentration over baseline value was noted after any glutamate dose. Thus, despite elevations in plasma glutamate concentrations after MSG loading, erythrocyte levels of glutamate and aspartate were unchanged.

\section{DISCUSSION}

Our data demonstrate similar plasma glutamate and aspartate concentration responses in infants and adults ingesting equal doses of glutamate on a $\mathrm{mg} / \mathrm{kg}$ body weight basis in a beef consommè. The mean plasma glutamate concentration response to glutamate loading at equivalent doses appears to be slightly less in infants than adults. At each glutamate dose, mean infant plasma AUC values for glutamate are lower than mean adult values. Similarly, at each dose of MSG, the mean peak increase over baseline for plasma glutamate is higher in adults than in infants.

The difference in plasma glutamate response to glutamate ingestion between adults and infants may reflect the more rapid rate of soup ingestion in adults, rather than an age-related phenomenon. The average time required for adults to ingest the soup was $7 \mathrm{~min}$, while the value in infants was $18 \mathrm{~min}$.

The more rapid clearance of glutamate from the blood by infants than by adults is consistent with other data we have obtained. Normal 1-yr-old infants appear to handle the methionine content of both $\mathrm{N}$-acetyl-L-methionine and L-methionine more rapidly than adults administered identical doses on a $\mathrm{mg} /$ $\mathrm{kg}$ body weight basis (11). Similarly, infants administered aspartame (L-aspartyl-L-phenylalanine methyl ester) at $100 \mathrm{mg} / \mathrm{kg}$ body weight clear aspartame's phenylalanine content from the blood somewhat more rapidly than adults (10).

The results of the present study are also consistent with our earlier data indicating good utilization of glutamate by term and premature infants $(9,12-14)$. However, in all of these earlier studies glutamate was administered in food that also contained large amounts of carbohydrate. We have recently shown that metabolizable carbohydrate appears to facilitate glutamate metabolism in both adult humans (15-17) and infant pigs (18). The net effect of simultaneous carbohydrate ingestion is a marked reduction in the plasma glutamate concentration increase noted 
following a fixed dose of MSG. Byun and Kim (19) also presented data consistent with the hypothesis that carbohydrate affects plasma glutamate concentration after glutamate ingestion.

Tung and Tung (20) reported data that could be interpreted to suggest that infants handle glutamate less well than adults. They administered MSG at $150 \mathrm{mg} / \mathrm{kg}$ body weight to premature and term infants (dissolved in infant formula) and adult subjects (porridge meal), reporting mean $( \pm \mathrm{SD})$ peak plasma glutamate levels of $24 \pm 5 \mu \mathrm{mol} / \mathrm{dl}$ in infants and $12.5 \pm 4 \mu \mathrm{mol} / \mathrm{dl}$ in adults. However, since the carbohydrate content of the food administered with glutamate varied between groups (formula for infants and porridge for adults), the plasma glutamate levels are not directly comparable. Further, the plasma glutamate levels observed by Tung and Tung (20) in infants and adults were significantly lower than values we observed in normal adults administered $150 \mathrm{mg} / \mathrm{kg}$ body weight of MSG in water, where peak plasma glutamate levels reached $59.4 \pm 46.5 \mu \mathrm{mol} / \mathrm{dl}(16)$. Thus, the data of Tung and Tung (20) may be explained by the effect of carbohydrate on glutamate metabolism.

In the present study, MSG was ingested in a consommè providing very little carbohydrate. Infants received approximately $700 \mathrm{mg}$ of carbohydrate when ingesting $160 \mathrm{ml}$ of the soup, or about $77 \mathrm{mg} / \mathrm{kg}$ body weight for a $9.1 \mathrm{~kg}$ infant. Because of the difference in volume administered, adult subjects ingested less carbohydrate (approximately $19 \mathrm{mg}$ of carbohydrate per $\mathrm{kg}$ body weight). This small amount of carbohydrate is unlikely to have a detectable effect on the plasma glutamate response in either infants or adults (17).

The quantities of MSG administered in this study represent a reasonable test of the expected intake of MSG from foods likely to be ingested by the young child. According to the Committee on GRAS List Survey-Phase III (21) the 99th percentile of expected daily intake of MSG by the 6-11-month-old infant is $36 \mathrm{mg} / \mathrm{kg}$ body weight, while that for the 11- to 23-month-old child is $43 \mathrm{mg} / \mathrm{kg}$ body weight. The 99.9 th percentiles for these two groups are 46 and $61 \mathrm{mg} / \mathrm{kg}$ body weight, respectively. Thus, the $50 \mathrm{mg} / \mathrm{kg}$ body weight dose of MSG studied approximated a value between the 99 and 99.9 th percentile of projected daily intake. Olney (1-3) had predicted a marked difference in the plasma glutamate response between infants and adults at an MSG dose of $50 \mathrm{mg} / \mathrm{kg}$ body weight.

Since we wished to avoid the confounding variable of carbohydrate's effect on glutamate metabolism, we chose a soup that contained as little carbohydrate as possible. Such consommè when sold commercially usually contains added MSG at levels varying from 0.15 to $0.30 \mathrm{~g} / 100 \mathrm{ml}$ as eaten. The consommè used in this study provided MSG at these levels. A $9.1 \mathrm{~kg}$ infant received a $0.165 \%$ solution of MSG when ingesting MSG at $25 \mathrm{mg} / \mathrm{kg}$ body weight dose and received a $0.308 \%$ solution when ingesting MSG at $50 \mathrm{mg} / \mathrm{kg}$ body weight dose.

However, it is possible for infants to receive larger amounts of MSG from soups than the doses investigated in this study. A Consumer Reports review (22) indicates that the MSG content of an average serving of soup reconstituted from commercially available dry soup bases is $735 \mathrm{mg}$, while soup with the largest amount of MSG provides $1300 \mathrm{mg}$ per serving. A $9.1 \mathrm{~kg} 1$-yrold ingesting an entire serving of soup providing an average amount of MSG would receive $81 \mathrm{mg} / \mathrm{kg}$ body weight, while an infant ingesting an entire serving of soup providing the largest amount of MSG would receive $143 \mathrm{mg} / \mathrm{kg}$ body weight. Infants ingesting restaurant soups may also receive higher doses of MSG. Olney (1-3) has suggested (without presenting supporting data) that restaurant soups may contain as much as $5 \mathrm{~g}$ of glutamate per serving. Conacher et al. (23) measured the MSG content of wonton soup from five restaurants, reporting a mean ( \pm SD) value of $1092 \pm 221 \mathrm{mg} / 100 \mathrm{ml}$. A $9.1 \mathrm{~kg}$ infant ingesting $6 \mathrm{oz}$ on average of wonton soup would receive $216 \mathrm{mg} \mathrm{MSG} / \mathrm{kg}$ body weight.

The use of glutamate as a food additive has been controversial.
Like other dicarboxylic amino acids, glutamate exerts toxic effects when administered at very high doses, although species and age susceptibility vary considerably. Neonatal rodents (24$28)$ and cats $(29,30)$ administered large doses of glutamate develop hypothalamic neuronal necrosis. There is disagreement over the ability of glutamate to produce neuronal necrosis in infant nonhuman primates. Olney and colleagues $(31,32)$ originally reported that large doses of glutamate given to neonatal nonhuman primates produced hypothalamic neuronal necrosis. However, four other laboratories were unable to find lesions in infant monkeys given equally large doses of MSG (33-43). The failure of these groups to observe lesions in neonatal nonhuman primates did not reflect a failure of the glutamate load to produce elevated plasma glutamate concentrations $(37,42)$. Furthermore, the latter investigators had no difficulty in producing the glutamate-induced lesion in infant rodents.

The critical question, however, is how these data relate to humans. The neonatal human probably resembles the neonatal monkey to a greater extent than the infant mouse. Thus, the negative findings noted in monkeys after administration of MSG by most investigators support its safety as a food additive. However, the controversy over the sensitivity of the infant nonhuman primate to MSG led us to explore additional ways of evaluating the potential neurotoxicity of MSG.

Although the neonatal mouse is sensitive to large doses of glutamate and aspartate, it tolerates substantial doses of these amino acids without developing neuronal necrosis. Doses of aspartate or glutamate that produce plasma glutamate plus aspartate concentrations lower than $60 \mu \mathrm{mol} / \mathrm{dl}$ (6 to 10 times normal) do not produce lesions in the infant rodent (44-49). Lesions are noted only when very large doses of glutamate or aspartate are administered and plasma glutamate plus aspartate concentrations exceed 60 to $100 \mu \mathrm{mol} / \mathrm{dl}$. Thus, plasma glutamate plus aspartate levels that are not harmful to infant mice should not be harmful to humans.

When MSG is given in water, the lowest dose producing lesions in infant mice is $500 \mathrm{mg} / \mathrm{kg}$ body weight (24-26). However, MSG doses of $500 \mathrm{mg} / \mathrm{kg}$ body weight or larger do not produce neuronal lesions when MSG is ingested with food $(50,51)$, a finding that is probably related to the effect of dietary carbohydrate on plasma glutamate concentration.

Infants ingesting $50 \mathrm{mg} \mathrm{MSG} / \mathrm{kg}$ body weight in consommè had a mean peak plasma glutamate plus aspartate concentration of $14.05 \mu \mathrm{mol} / \mathrm{dl}$, a level that would not be considered potentially harmful to even the neonatal mouse. It is not clear what the plasma glutamate concentration response would be in infants ingesting soup providing larger quantities of MSG. If infants and adults metabolize glutamate equally well at higher doses of MSG than those studied in this report, data obtained in adults can be used to predict values in infants. Such regression curves based on adult data (4) indicate that an MSG dose of $150 \mathrm{mg} / \mathrm{kg}$ body weight, ingested in consommè, bouillon, or tomato juice, would result in a mean peak plasma glutamate concentration of 50 to $60 \mu \mathrm{mol} / \mathrm{dl}$. This projected plasma glutamate plus aspartate concentration (50 to $60 \mu \mathrm{mol} / \mathrm{dl}$ ) approaches the threshold value associated with toxicity in the infant mouse, but is still far below the no effect level of $450 \mu \mathrm{mol} / \mathrm{dl}$ observed in the infant nonhuman primate $(37,42)$. If, on the other hand, infants metabolize larger doses of MSG more slowly than adults, the plasma glutamate concentration response will be larger in infants than in adults. However, the precise response is difficult to predict since no human studies suggest such an effect. Studies in infant and adult nonhuman primates administered $500 \mathrm{mg} \mathrm{MSG} / \mathrm{kg}$ body weight indicate that the mean peak plasma glutamate concentration in infant monkeys is twice as high as the value in adults (45). If this factor is applied to humans, such projections indicate that infants ingesting $150 \mathrm{mg} \mathrm{MSG} / \mathrm{kg}$ body weight might have a mean peak plasma glutamate concentration of 100 to 120 $\mu \mathrm{mol} / \mathrm{dl}$. This putative plasma glutamate concentration would 
exceed the threshold value associated with toxicity in the infant mouse, but would still be within the no effect plasma glutamate range in the infant nonhuman primate $(37,42)$.

Attempts to predict the peak plasma glutamate plus aspartate concentration produced by ingestion of commercial soups containing large amounts of glutamate are complicated by the fact that such soups contain significant amounts of carbohydrate. Thus, mean peak plasma glutamate concentration should be lower than 50 to $60 \mu \mathrm{mol} / \mathrm{dl}$ when humans ingest soup that provides $150 \mathrm{mg} / \mathrm{kg}$ body weight MSG and contains carbohydrate [see for example the data of Tung and Tung (20)]. However, the soup must contain significant amounts of carbohydrate to produce a lower plasma glutamate concentration. Our data in adults suggest that the carbohydrate effect on glutamate metabolism is only noted when the carbohydrate dose exceeds $0.25 \mathrm{~g} /$ $\mathrm{kg}$ body weight (17).

Acknowledgments. This project would not have been possible without the assistance of B. Edwards, M. Burch, J. Franz, and D. Hale of the Lora N. Thomas Pediatric Metabolism Unit.

\section{REFERENCES}

1. Olney JW 1982 Excitatory neurotoxins as food additives: an evaluation of risk. Neurotoxicology 2:163-192

2. Olney JW 1982 The toxic effects of glutamate and related compounds in the retina and the brain. Retina 2:341-359

3. Olney JW 1984 Excitotoxic food additives-relevance of animal studies to human safety. Neurobehav Toxicol Teratol 6:455-462

4. Stegink LD, Filer LJ Jr, Baker GL 1985 Plasma glutamate concentrations in adult subjects ingesting monosodium L-glutamate in consommé. Am J Clin Nutr 42:220-225

5. Stegink LD, Filer LJ Jr, Baker GL: 1982 Effect of sampling site on plasma amino acid concentrations of infants: Effect of skin amino Acids. Am J Clin Nutr 36:917-925

6. Steel RGD, Torrie JH 1960 Principles and Procedures of Statistics. McGrawHill, New York

7. Morrison DF 1976 Multivariate Statistical Methods, 2nd ed. McGraw-Hill, New York, pp 216-222

8. Miller RG Jr 1966 Simultaneous statistical inferrence. McGraw-Hill, New York, pp 67-70

9. Filer LJ Jr, Baker GL, Stegink LD 1979 Metabolism of free glutamate in clinical products fed infants. In: Filer LJ Jr, Garattini S, Kare MR, Reynolds WA, Wurtman RJ (eds) Glutamic Acid: Advances in Biochemistry and Physiology. Raven Press, New York, pp 353-362

10. Filer LJ Jr, BakerGL, Stegink LD 1983 Effect of aspartame loading on plasma and erythrocyte free amino acid concentrations in one-year-old infants. J Nutr 113:1591-1599

11. Stegink LD, Filer LJ Jr, Baker GL 1981 Plasma and urinary methionine levels in one-year-old infants after oral loading with $\mathrm{L}$-methionine and $\mathrm{N}$-acetyl-Lmethionine. J Nutr 112:597-603

12. Stegnik LD, Baker GL 1971 Infusion of protein hydrolysates in the newborn infant: Plasma amino acid concentrations. J Pediat 78:595-663

13. Bell EF, Filer LJ Jr, Wong AP, Stegink LD 1983 Effect of parenteral nutrition regimens containing dicarboxylic amino acids upon plasma, erythrocyte and urinary amino acid concentrations in young infants. Am J Clin Nutr 37:99107

14. Stegink LD, Bell EF, Daabees TT, Andersen DW, Zike WL, Filer LJ Jr 1983 Factors influencing utilization of glycine, glutamate and aspartate in clinical products. In: Blackburn G, Grant J, Young V (eds) Amino acids: Metabolism and Medical Applications. Wright-PSG Publishing Co., Littleton, MA, pp $123-146$

15. Stegink LD, Baker GL, Filer LJ Jr 1983 Modulating effect of Sustagen on plasma glutamate concentrations in humans ingesting monosodium L-glutamate. Am J Clin Nutr 37:194-200

16. Stegink LD, Filer LJ Jr, Baker GL 1983 Effect of carbohydrate on plasma and erythrocyte glutamate levels in humans ingesting large doses of monosodium L-glutamate in water. Am J Clin Nutr 37:961-968

17. Stegink LD, Filer LJ Jr, Baker GL 1985 Effect of starch ingestion on plasm glutamate concentrations in humans ingesting monosodium L-glutamate in soup. J Nutr 115:211-218

18. Daabees TT, Andersen DW, Zike WL, Filer LJ Jr, Stegink LD 1984 Effect of meal components on peripheral and portal plasma glutamate levels in young pigs administered large doses of monosodium L-glutamate. Metabolism 33:58-67

19. Byun SM, Kim HS 1980 Human development: human serum glutamate levels of Koreans. Nutr Rep Int 22:697-705

20. Tung T-C, Tung K-S 1980 Serum free amino acid levels from oral glutamate intake in infant and adult humans. Nutr Rep Int 22:431-443

21. Appendix E. Estimating distributions of daily intake of monosodium glutamate
(MSG). In: Estimating Distribution Of Daily Intake of Certain GRAS Substances. Committee on GRAS List Survey-Phase III, Food and Nutrition Board, Division of Biological Sciences, Assembly of Life Sciences, National Research Council, National Academy of Sciences, Washington, DC, 1976.

22. Consumers Union 1978 Dried soup mixes (this is soup?). Consumer Rep November, 615-619

23. Conacher HBS, Iyengar JR, Miles WF 1979 Gas-liquid chromatographic determination of monosodium glutamate in soups and soup bases. J Assoc Off Anal Chem 62:604-609

24. Olney JW 2969 Brain lesions, obesity, and other disturbances in mice treated with monosodium glutamate. Science 164:719-721

25. Lemkey-Johnston N, Reynolds WA 1974 Nature and extent of brain lesions in mice related to ingestion of monosodium glutamate: a light of electron microscope study. J Neuropathol Exp Neurol 33:74-97

26. Olney JW, Ho O-L 1970 Brain damage in infant mice following oral intake of glutamate, aspartate or cysteine. Nature 227:609-610

27. Tafelski TJ, Lamperti AA 1977 Effects of a single injection of monosodium glutamate on the reproductive neuroendocrine axis of the female hamster. Biol Reprod 17:404-411

28. Lamperti A, Blaha $G 1976$ The effects of neonatally-administered monosodium glutamate on the reproductive system of adult hamsters. Biol Reprod 14:362369

29. Shimada M, Wakamatsu H, Tanaka K, Nakao H, Kusunoki T 1975 Brain damage during the growth phase due to excessive administration of $\mathrm{L}$-form amino acids. Acta Pediatr Jpn 79:983-984

30. Applebaum AE, Daabees TT, Filer LJ Jr, Stegink LD 1981 Hypothalamic neuronal necrosis in neonatal cats administered pharmacologic doses of monosodium L-glutamate. Soc Neurosci Abstr 7:89

31. Olney JW, Sharpe LG 1969 Brain lesions in an infant rhesus monkey treated with monosodium glutamate. Science 166:386-388

32. Olney JW, Sharpe LG, Feigin RD 1972 Glutamate-induced brain damage in infant primates. J Neuropathol Exp Neurol 31:464-488

33. Reynolds WA, Lemkey-Johnston N, Filer LJ Jr, Pitkin RM 1971 Monosodium glutamate: absence of hypothalamic lesions after ingestion by newborn primates. Science 172:1342-1344

34. Abraham R, Dougherty W, Golberg L, Coulston F 1971 The response of the hypothalamus to high doses of monosodium glutamate in mice and monkeys. Cytochemistry and ultrastructural study of lysosomal changes. Exp Mol Pathol 15:43-60

35. Newman AJ, Heywood R, Palmer AK, Barry DH, Edwards FP, Worden AN 1973 The administration of monosodium-L-glutamate to neonatal and pregnant primates. Toxicology 1:197-204

36. Wen CP, Hayes KC, Gershoff SN 1973 Effects of diatary supplementation of monosodium glutamate on infant monkeys, weanling rats and suckling mice. Am J Clin Nutr 26:803-813

37. Stegink, LD, Reynolds WA, Filer LJ Jr, Pitkin RM, Boaz DP, Brummel MC 1975 Monosodium glutamate metabolism in the neonatal monkey. Am J Physiol 229:246:250

38. Abraham R, Swart J, Golberg L, Coulston F 1975 Electron microscopic observations of hypothalami in neonatal rhesus monkeys (Macaca mulatta) after administration of monosodium-L-glutamate. Exp Mol Pathol 23:203213

39. Reynolds WA, Butler V, Lemkey-Johnston N 1976 Hypothalamic morphology following ingestion of aspartame or MSG in the neonatal rodent and primate. A preliminary report. J Toxicol Environ Health 2:471-480

40. Reynolds WA, Lemkey-Johnston N, Stegink LD 1979 Morphology of the feta monkey hypothalamus after in utero exposure to monosodium glutamate. In: Filer LJ Jr, Garattini S, Kare MR, Reynolds WA, Wurtman RJ, (eds) Glutamic Acid: Advances in Biochemistry and Physiology. Raven Press, New York, pp 217-229

4. Heywood R, Worden AN 1979 Glutamate toxicity in laboratory animals. In: Filer LJ Jr, Garattini S, Kare MR, Reynolds WA, Wurtman RJ, (eds) Glutamic Acid: Advances in Biochemistry and Physiology. Raven Press, New York, pp 203-215

42. Reynolds, WA, Stegink LD, Filer LJ Jr, Renn E 1980 Aspartame administration to the infant monkey: hypothalamic morphology and plasma amino acid levels. Anat Rec 198:73-85

43. Heywood R, James RW 1979 An attempt to induce neurotoxicity in an infant rhesus monkey with monosodium glutamate. Toxicol Lett 4:285-286

44. Stegink LD, Shepherd JA, Brummel MC, Murray LM 1974 Toxicity of protein hydrolysate solutions: Correlation of glutamate dose and neuronal necrosis to plasma amino acid levels in young mice. Toxicology 2:285-299

45. Stegink LD, Reynolds WA, Filer LJ Jr, Baker GL, Daabees TT, Pitkin RM, 1979 Comparative metabolism of glutamate in the mouse, monkey, and man. In: Filer LJ Jr, Garattini S, Kare MR, Reynolds WA, Wurtman RJ (eds) Glutamic Acid: Advances in Biochemistry and Physiology, Raven Press, New York, pp 85-102

46. Itoh H, Kishi T, Iwasawa Y, Kawashima K, Chibata I 1979 Plasma aspartate levels in rats following administration of monopotassium aspartate via three routes. J Toxicol Sci 4:377-388

47. Takasaki Y, Matsuzawa Y, Iwata S, O'Hara Y, Yonetani S, Ichimura M 1979 Toxicological studies of monosodium L-glutamate in rodents: relationship between routes of administration and neurotoxicity. In: Filer LJ Jr, Garattini S, Kare MR, Reynolds WA Wurtman RJ (eds) Glutamic Acid: Advances in Biochemistry and Physiology. Raven Press, New York, pp 225-275 
48. O'Hara Y, Takasaki Y 1979 Relationship between plasma glutamate levels and hypothalamic lesions in rodents. Toxicol Lett 4:499-505

49. Daabees TT, Finkelstein MW, Stegink LD, Applebaum AE 1985 Correlation of glutamate plus aspartate dose, plasma amino acid concentration and neuronal necrosis in infant mice. Food Chem Toxicol (in press)

50. Takasaki Y 1978 Studies on brain lesions after administration of monosodium L-glutamate to mice. II. Absence of brain damage following administration of monosodium l-glutamate in the diet. Toxicology 9:307-318

51. Anantharaman K 1979 In utero and dietary administration of monosodium L-glutamate to mice: reproductive performance and development in a multigeneration study. In: Filer LJ Jr, Garattini S, Kare MR, Reynolds WA, Wurtman RJ, (eds) Glutamic Acid: Advances in Biochemistry and Physiology. Raven Press, New York, pp 231-253

\section{ANNOUNCEMENTS}

\section{First I.U.I.S. Conference on Clinical Immunology}

A 2-day conference on clinical immunology will be held in conjunction with the VIth International Congress of Immunology, in Toronto, Canada, from July 5-6, 1986. These dates immediately precede the VIth International Congress. The conference will encompass plenary sessions, minisymposia, and a poster session. Among the major topics: receptor-anti-receptor mediated diseases; new trends in the management of disorders of autoimmunity, immunodeficiency, allergy, immunodiagnostic techniques, and transplantation; and a session concerned with human diseases caused by lymphotropic retroviruses.

Registration and abstract forms may be obtained from: Mr. K. Charbonneau, National Research Council of Canada, Ottawa, Ontario K1A OR6, Canada.

\section{0th International Convocation on Immunology Buffalo, NY, July 14-17, 1986 \\ Vaccines: New Concepts and Developments}

The Ernest Witebsky Center for Immunology will present this symposium in its regular biennial series at the Hyatt Regency Buffalo Hotel following the VIth International Congress of Immunology in Toronto, Canada, which is only 100 miles distant. Closed plenary sessions will focus on the topics: Conceptual Basis of Antigens; Antigen Identification and Purification; Host Response; Production of Vaccines by Recombinant DNA Techniques: Idiotype Vaccines; and Human and Veterinary Vaccines. Open poster sessions for free contributions on the theme will be offered.

For further information contact: Dr. James F, Mohn, Director, The Ernest Witebsky Center for Immunology, 210 Sherman Hall, State University of New York at Buffalo, Buffalo, NY 14214 (716-831-2848). 